\title{
MMTV-NeuT/ATTAC mice: a new model for studying the stromal tumor microenvironment
}

This article has been corrected. Correction in Oncotarget. 2018; 9:37808-37808.

Hongyan Yuan ${ }^{1}$, Xiaoyi Wang ${ }^{1}$, Jin Lu${ }^{1}$, Qiongsi Zhang ${ }^{1}$, Irina Brandina ${ }^{2}$, Ilya Alexandrov ${ }^{2}$ and Robert I. Glazer ${ }^{1}$

${ }^{1}$ Department of Oncology, Lombardi Comprehensive Cancer Center, Georgetown University Medical Center, Washington, DC 20007, USA

${ }^{2}$ ActivSignal, LLC, Natick, MA 01760, USA

Correspondence to: Robert I. Glazer, email: glazerr@georgetown.edu

Keywords: fibrosis; mammary tumorigenesis; NeuT; adipose tissue; chemokines

Received: May 12, $2017 \quad$ Accepted: January 09, $2018 \quad$ Published: January 15, 2018

Copyright: Yuan et al. This is an open-access article distributed under the terms of the Creative Commons Attribution License 3.0 (CC BY 3.0), which permits unrestricted use, distribution, and reproduction in any medium, provided the original author and source are credited.

\section{ABSTRACT}

One of the central challenges in cancer prevention is the identification of factors in the tumor microenvironment (TME) that increase susceptibility to tumorigenesis. One such factor is stromal fibrosis, a histopathologic negative prognostic criterion for invasive breast cancer. Since the stromal composition of the breast is largely adipose and fibroblast tissue, it is important to understand how alterations in these tissues affect cancer progression. To address this question, a novel transgenic animal model was developed by crossing MMTV-NeuT mice containing a constitutively active ErbB2 gene into the FAT-ATTAC (fat apoptosis through targeted activation of caspase 8 ) background, which expresses an inducible caspase 8 fusion protein targeted to mammary adipose tissue. Upon caspase 8 activation, lipoatrophy of the mammary gland results in stromal fibrosis and acceleration of mammary tumor development with an increase in tumor multiplicity. Fibrosis was accompanied by an increase in collagen deposition, a-smooth muscle actin and CD31 expression in the tumor stroma as well as an increase in PD-L1-positive tumor cells, and infiltration by regulatory T cells, myeloid-derived suppressor cells and tumor-associated macrophages. Gene expression and signal transduction profiling indicated upregulation of pathways associated with cytokine signaling, inflammation and proliferation. This model should be useful for evaluating new therapies that target desmoplasia in the TME associated with invasive cancer.

\section{INTRODUCTION}

Over the past decade, it has become increasingly apparent that the cell-centric hallmarks of cancer originally proposed [1] are exceedingly more complex, and must now take into account the multi-faceted role and interplay of multiple cell types in the tumor microenvironment (TME) [2-5]. Although the TME is emerging as an important determinant of tumorigenesis and as an attractive target for therapy [6], understanding the specific cellular and molecular changes in the TME associated with breast cancer risk remains one of the overarching challenges for the prevention and treatment of this disease. The breast is composed of several stromal elements, among which adipose and fibrotic tissue comprise the largest components. Breast density increases with an increasing ratio of glandular and fibrous tissue to adipose tissue, making mammographic diagnosis more difficult and increasing the likelihood of developing breast cancer [7-10]. Since stromal fibrosis is a histopathologic criterion for predicting invasive breast cancer [11, 12], metastasis [13] and the development of precancerous lesions [14], the identification of coordinated signaling pathways between tumor and stromal cells would greatly 
aid our understanding of their roles in tumorigenesis. During transition from pre-invasive to invasive ductal breast carcinoma, the TME undergoes extensive changes due to secretion of inflammatory factors by tumor cells and cancer-associated fibroblasts and macrophages [15, 16]. Stromal fibroblasts secrete chemokines, such as Cxcl1, which promote angiogenesis, growth, invasion [17] and metastasis in breast cancer $[17,18]$ as well as reduced survival in colorectal, bladder and prostate cancers [19-21]. Cxcl1 and Ccl2 [22] facilitate immune tolerance by recruiting and activating regulatory $\mathrm{T}$ cells (Treg) and myeloid-derived suppressor cells (MDSC), which reduce activation of $\mathrm{CD}^{+}$cytotoxic effector $\mathrm{T}$ cells $[23,24]$. This outcome suggests that therapy targeting, in part, chemokine receptor pathways including Cxcl1/Cxcr2, may be an effective approach for reducing or preventing the tumor-promoting effect of the inflammatory TME [25, 26].

Thus far, there is a paucity of relevant animal models for studying the relationship between mammary fibrosis and tumorigeneses. To develop a better understanding of this relationship, we developed a unique erbB2 oncogenic mouse model in which stromal fibrosis could be induced conditionally by the selective ablation of mammary adipose tissue. Here we report our initial observations of the impact of stromal fibrosis on erbB2-mediated mammary tumorigenesis.

\section{RESULTS}

\section{Induction of stromal fibrosis and tumor development}

NeuT/ATTAC mice were generated as a conditional model of breast fibrosis, which is associated with high mammographic density and invasive breast cancer [7-9, 27]. In this model, desmoplasia is induced in the mammary fat pad of female mice by drug-induced dimerization of the FKBPv-caspase 8 fusion protein targeted to adipocytes by the dimerizer AP21087 [28] (Figure 1A). Whole mounts of the mammary gland from FAT-ATTAC or NeuT/ATTAC mice treated with vehicle or AP21087 three times per week for two weeks produced increased ductal branching and a reduction in fat pad invasion (Figure 1B). AP21087 treatment resulted in loss of mammary adipose tissue in FAT-ATTAC and NeuT/ATTAC mice, which was accompanied by the initial stages of fibrosis (Figure 1C). AP21087 treatment of mice lacking the FATATTAC background did not alter the fat composition of the mammary gland or produce fibrosis (not shown).

Longer term studies were then initiated to develop a baseline for the development of fibrosis. NeuT/ATTAC mice were treated with vehicle or AP-21087 three times per week for four weeks, which resulted in a pronounced loss of mammary fat and increased epithelial proliferation as determined by Ki-67 staining (Figure 2). These changes were accompanied by increased expression of biomarkers associated with angiogenesis (CD31) and fibrosis (SMA and collagen types I and III staining with PicroSirius Red). In addition, chemokine Cxcl1 and PD-L1 associated with immune tolerance were expressed in non-tumor tissue of the TME and correlated with the onset of macrophage and Treg infiltration as denoted by F4/80 and Foxp3 staining, respectively.

To derive a better understanding between fibrosis and tumorigenesis, NeuT/ATTAC mice were treated with AP21087 or vehicle for four to six months in order to encompass the approximate median times of tumor formation (see Figure 4A). The longer treatment regimen resulted in more pronounced changes in the parameters measured after four weeks of AP21087 treatment, but resulted in greater Foxp $3^{+}$Treg and lesser $\mathrm{CD}^{+} \mathrm{T}$ cell filtration into the TME (Figure 3). Associated with the development of fibrosis was in a reduction in tumor latency from a median of approximately 160 days in mice treated with vehicle to 100 days following AP21087 treatment (Figure 4A), and an increase in tumor multiplicity from 7 tumors/mouse in vehicle-treated animals to 15 tumors/ mouse in AP21087-treated animals (Figure 4B).

\section{Gene expression and cell signaling analysis}

Gene expression analysis was next evaluated in mammary tumors developing at 4 months in AP21087treated NeuT/ATTAC mice or at 5.5 months in vehicletreated mice. Tumors from AP21087-treated NeuT/ATTAC mice resulted in marked changes in gene expression (Figure 3C), including upregulation of genes associated with adhesion (Clca1, Clca2, Krt19), inflammation/ immunity (Saa1, CD14, Btn1a1, Ltb, Cxcl1, Ccl5, Saa1), invasion (Spp1), metabolism (Pla2g7), proliferation (Bex1, Basp1, Hsp1a1) and translation (Rps9), and a marked reduction in the adipose-specific genes Fabp4, Apo191 and Adipoq (Supplementary Table 2). Several of the changes in gene expression were confirmed by qRT-PCR (Figure 3D), and are summarized in Table 1. Similar gene expression profiling was conducted on mammary tissue after four weeks of AP21087 treatment (Supplementary Table 3). Interestingly, four weeks of AP21087 treatment produced a five-fold greater number of changes in gene expression as occurred in tumors after four months of treatment (Supplementary Table 3), including downregulation of $85 \%$ of metabolic genes, which accounted for more than $40 \%$ of the total changes in gene expression.

To obtain a better understanding of the changes in signal transduction occurring in tumors from NeuT/ ATTAC mice after four months of AP21087 treatment, FFPE tumor sections were assessed for changes in 20 pathways by immuno-paired antibody detection (IPAD) for 73 phospho- and nonphospho-proteins (Figure 3E). IPAD analysis revealed significant upregulation in four major processes associated with proliferation ( $\mathrm{pCDK} 1)$, 
cytokine signaling (pCbl, pKit, pSyk and Socs3), protein processing (Hsp70/Hsp1a1, pHsp27/Hspb1) and inflammation (pIKK) in tumors from AP21087-treated mice versus vehicle-treated mice (Figure $3 \mathrm{E}$ ).

\section{DISCUSSION}

The present study describes a unique conditional model of mammary desmoplasia in which stromal fibrosis

A

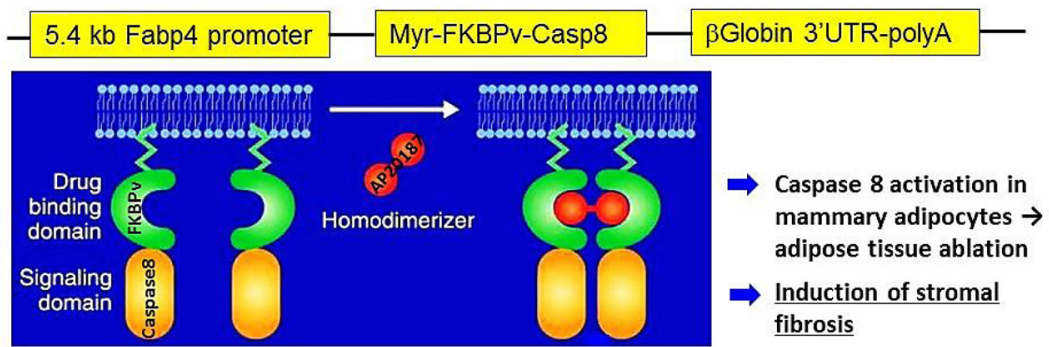

Approach:

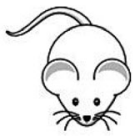

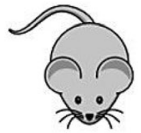

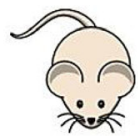

MMTV-NeuT $\times$ FAT-ATTAC $=$ NeuT/ATTAC

B

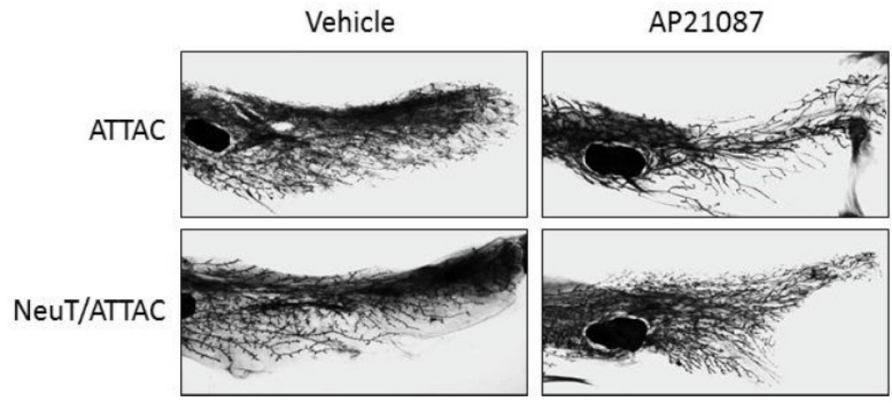

C
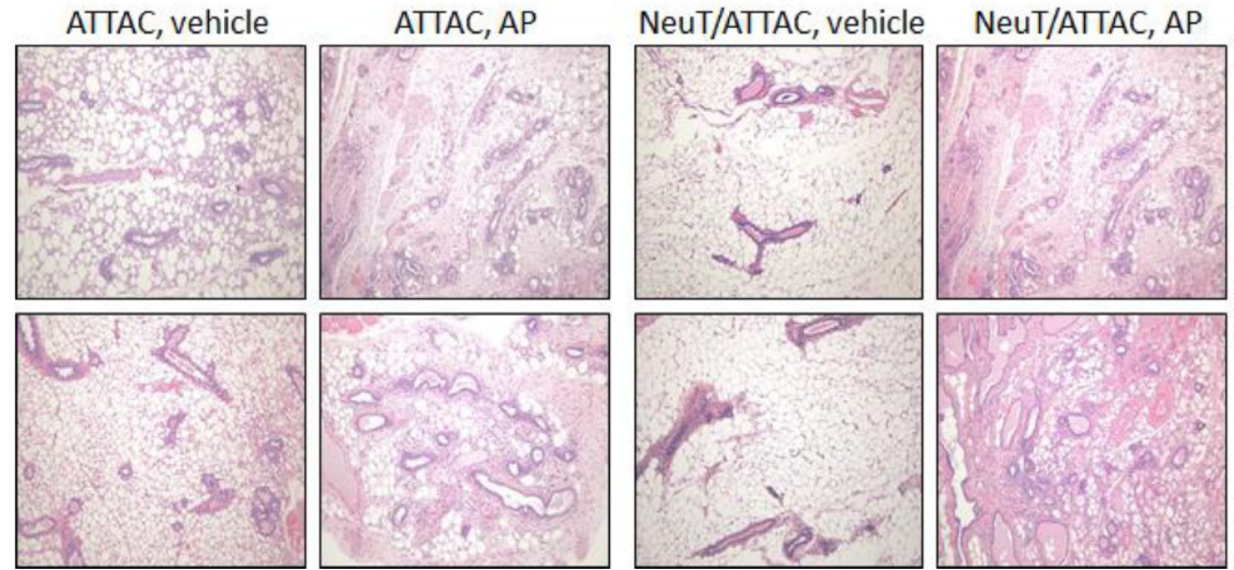

Figure 1: Conditional NeuT/ATTAC mice. (A) Schematic of the generation of NeuT/ATTAC mice. FAT-ATTAC mice express a myristoylated-FKBPv-caspase 8 fusion protein under the control of the adipose-selective minimal Fabp4 promoter. Caspase is activated by dimerization of adjacent FKBPv domains (green) by the dimerizer AP21087 (red). Mouse color is for illustrative purposes and does not reflect genetic background. (B) Whole mounts of the mammary gland from FAT-ATTAC (ATTAC) or NeuT/ATTAC mice treated with vehicle or AP21087 for two weeks. Fat pad ablation increased ductal branching and reduced invasion of the fat pad. Magnification 10×, (C) H\&E staining of the mammary gland treated with vehicle or AP21087 for two weeks as in (B). Two different tissue sections per group are shown. Loss of adipose tissue in ATTAC and NeuT/ATTAC mice following AP21087 treatment was accompanied by the initial stages of fibrosis. Treatment of MMTV-NeuT mice with AP21087 did not alter the composition of the mammary gland (not shown). Magnification $400 \times$. 
can be induced selectively in the mammary gland to study its link to tumor progression. It is well-established that the TME undergoes extensive changes during transition from pre-invasive to invasive ductal breast carcinoma, which results in changes in adaptive immunity [29] and poor outcomes [30]. The repertoire of stromal cell types, particularly cancer-associated fibroblasts, impacts every facet of transformation [5, 31-33], which was evident by interaction analysis of tumor genes upregulated by fibrosis (Figure 5). These changes encompassed every facet of tumor development, including adhesion, immune regulation, inflammation, mitosis, motility, oxidative stress and vascularization. Many of these changes were consistent with increased deposition of collagen associated with high breast density [27], the development of large fibrotic foci and early metastases in hormone receptor-negative breast cancer [11], identification of CD52, Spp1 and Cxcl14 in the stromal gene expression signature in breast cancer subjects [30], and the greater expression of Spp1 in HER2+ and triple-negative breast cancer [34].
One of the hallmarks of fibrosis is the aberrant secretion of chemokines which results in increased inflammation and activation of immune cells associated with immune tolerance [33]. These characteristics were indicative of tumors from NeuT/ATTAC mice, which exhibited increased $\mathrm{Cxcl1}$ and $\mathrm{Ccl} 5$ expression (Table 1), but were not present in mammary tissue from mice treated for four weeks (Supplementary Table 3), suggesting that these changes are not early events accompanying fibrosis. This interpretation is supported by the lesser degree of immune cell infiltration at four weeks after AP21087 treatment (Figure 2) in comparison to longer treatment intervals (Figure 3). Cxcl1 and other chemokines [22] facilitate immune tolerance in part by recruiting and activating Treg and MDSC to block activation of $\mathrm{CD}^{+}$effector $\mathrm{T}$ cells $[23,24]$. Cxcl1 modulates MDSC infiltration in prostate tumors [35] and rhabdomyosarcomas [26], is a prognostic marker of poor outcome in breast cancer [36] and promotes metastasis in an MDA-MB-231 breast cancer xenograft model [18]. Cxcr2 antagonists not only to reduce metastasis, tumor

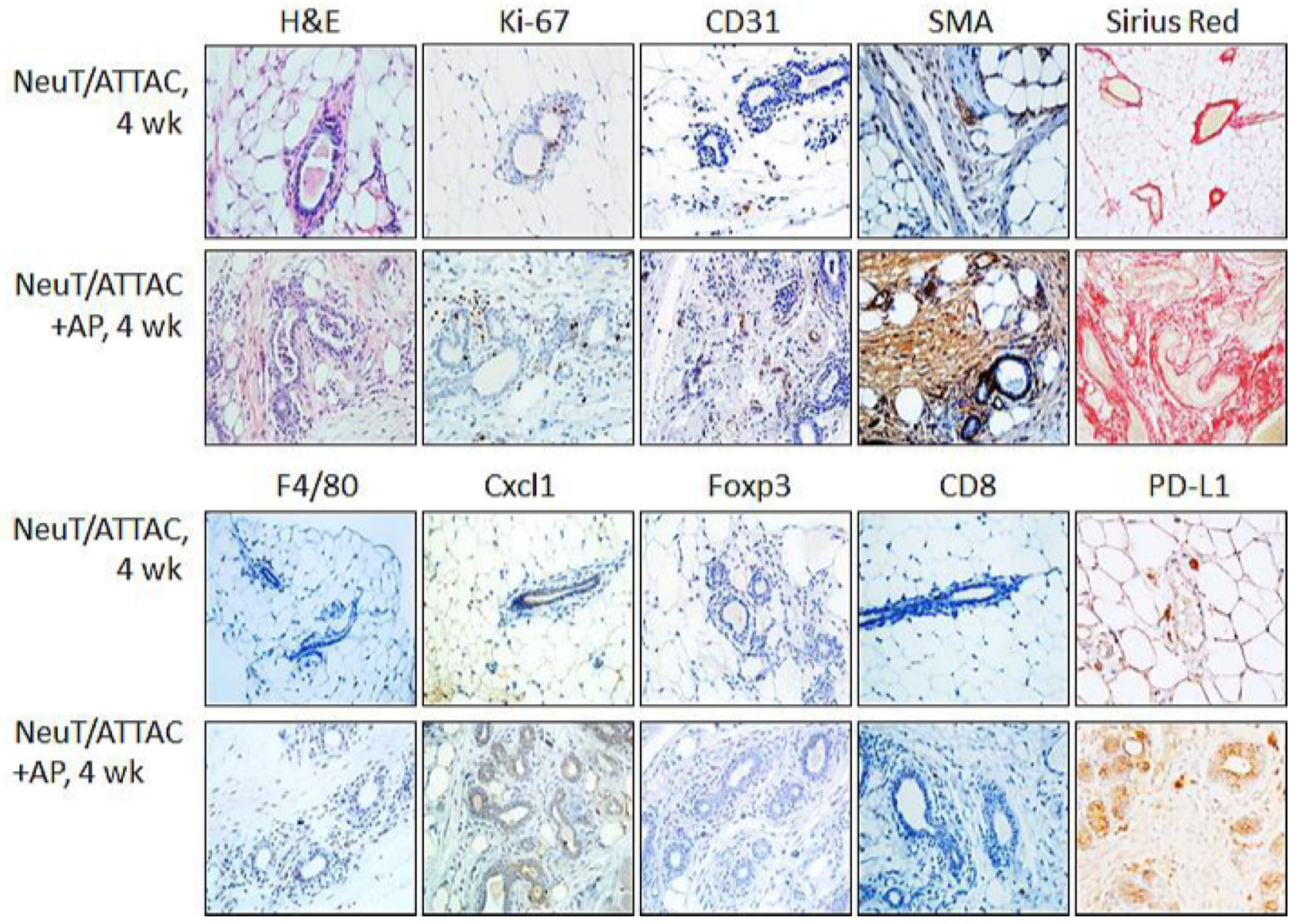

Figure 2: Induction of fibrosis in the mammary gland of NeuT/ATTAC mice following AP21087 treatment for four weeks. Six-week-old NeuT/ATTAC mice were injected i.p. with vehicle (NeuT/ATTAC) or $0.4 \mathrm{mg} / \mathrm{kg} \mathrm{AP21087} \mathrm{(NeuT/ATTAC+AP)}$ for four weeks. FFPE sections were stained as described in Figure 2. Magnification 400×. 
growth and improve response to chemotherapy in the xenograft model [18], but suppress inflammation-driven intestinal adenocarcinomas [25] and improve survival in a KRas-driven pancreatic ductal adenocarcinoma model [37]. Since many chemokine receptor antagonists have been developed and tested clinically in chronic inflammatory disorders $[38,39]$, it may be a useful strategy to employ these drugs as adjuvants for enhancing the efficacy of cancer therapy $[25,26]$.

IPAD analysis revealed that signaling mediated through Hsp70 and c-Kit were significantly upregulated in tumors from NeuT/ATTAC mice. These novel findings were not predicted by gene expression profiling and provide a unique technology for phenotyping tumors. In this regard, it is noted that the c-Kit inhibitor imatinib inhibited breast stromal fibroblasts and reduced tumor growth [40], and that c-Kit/CSF1R inhibitors target tumorpromoting M2 macrophages in the TME of solid tumors [41]. IPAD also identified heat-shock protein regulation as a potential therapeutic strategy as noted by the ability of the Hsp90 inhibitor geldanamycin to promote ErbB2 degradation in SKBR breast cancer cells [42].

Lastly, since loss of mammary fat elicited fibrosis, the reverse situation of inducing white adipose fat differentiation by PPARg agonists might be considered to suppress fibrosis [43]. However, mammary fibrosis in NeuT/ATTAC mice is distinct from adipose tissue fibrosis in the epididymal and mesenteric fat of male mice [43], where collagen VI predominates in contrast to collagen I and III in the mammary fat pad. Thus, it is uncertain if $\operatorname{PPAR} \gamma$ agonists will have a beneficial effect as an antifibrotic therapy in breast cancer. An alternate approach to reduce mammary fibrosis and tumorigenesis in caveolin1-deficient MMTV-PyMT utilized rapamycin since this model exhibits increased mTOR signaling [44]. Although this approach was also successful as an antitumor therapy in MMTV-PPAR $\delta$ mice [45], NeuT/ATTAC mice do not display increased mTOR signaling or reduced caveolin-1 or -2 expression, and therefore rapamycin, at least in this context, would not be expected to have efficacy in NeuT/ ATTAC mice.

In summary, induction of stromal fibrosis in the mammary gland accelerated tumor formation in MMTVNeuT transgenic mice. This occurred in conjunction with upregulation of genes associated with growth, vascularization and immune regulation, and specifically with signaling pathways mediated through c-Kit, CDK1 and NFkB. These outcomes suggest several new therapeutic strategies to modify or reduce tumor progression.

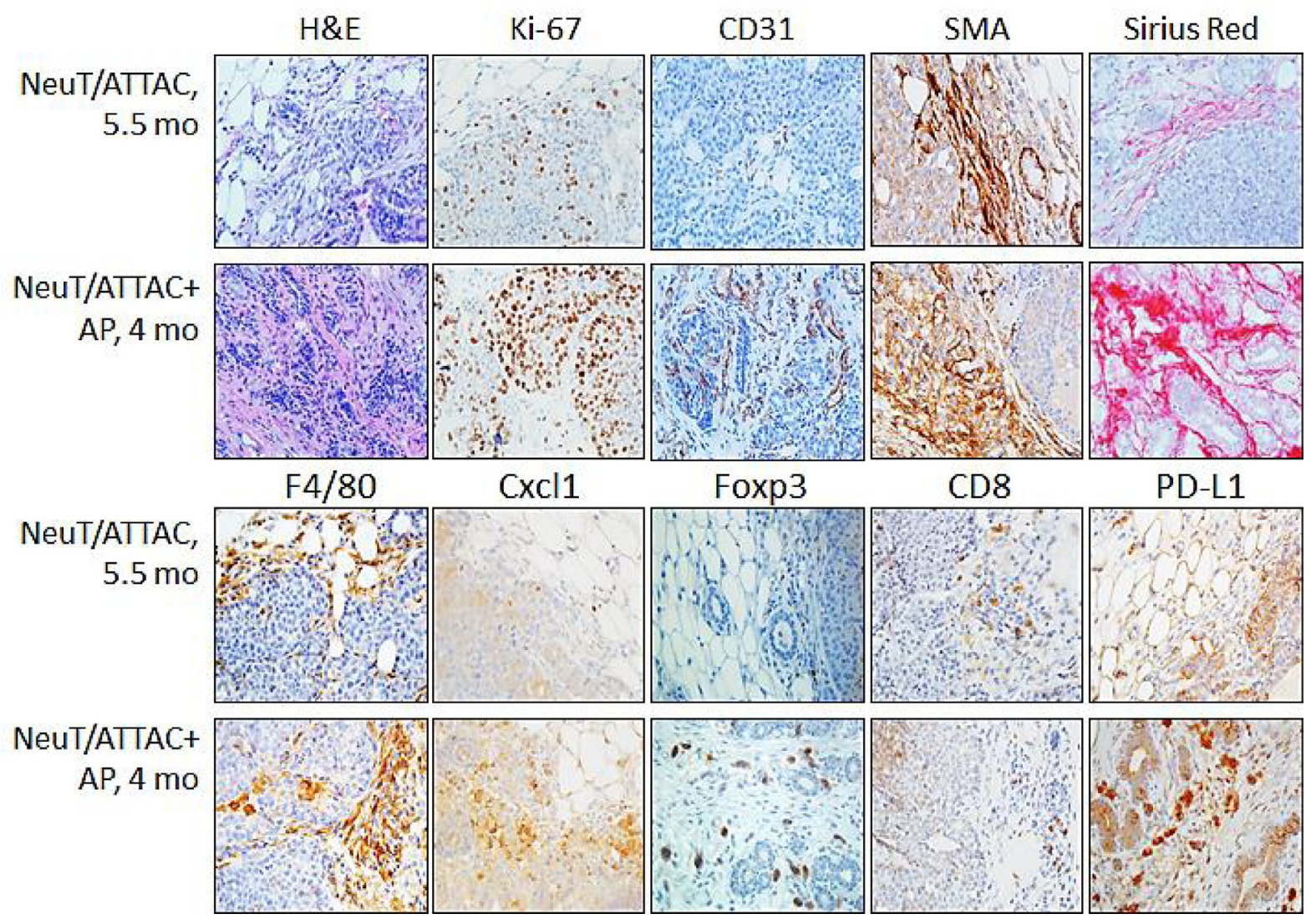

Figure 3: Induction of fibrosis in NeuT/ATTAC mice. Mice at 6 weeks-of-age were injected i.p. with vehicle (NeuT/ATTAC) three times weekly for 5.5 months (NeuT/ATTAC) or with $0.4 \mathrm{mg} / \mathrm{kg} \mathrm{AP2} 1087$ (NeuT/ATTAC+AP) for 4 months. FFPE sections were stained with H\&E, for collagen (PicroSirius Red) and with antibodies against Ki-67, CD31, $\alpha$-smooth muscle actin (SMA), F4/80, Cxcl1, Foxp3, CD8 and PD-L1. Magnification 400×. 
A

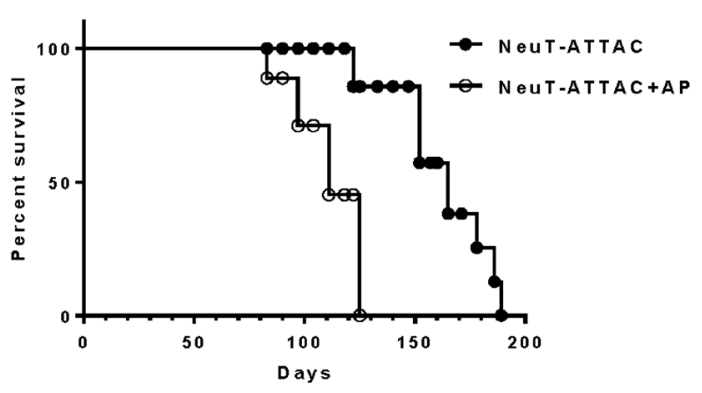

B

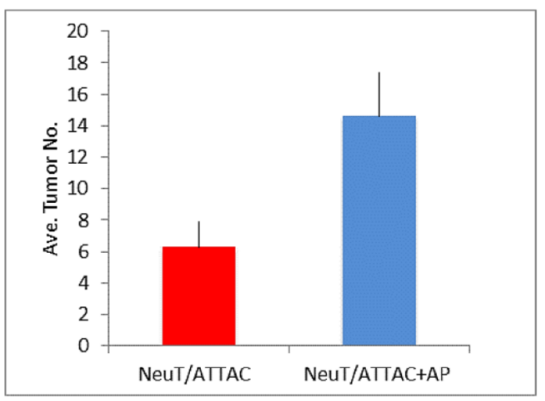

C
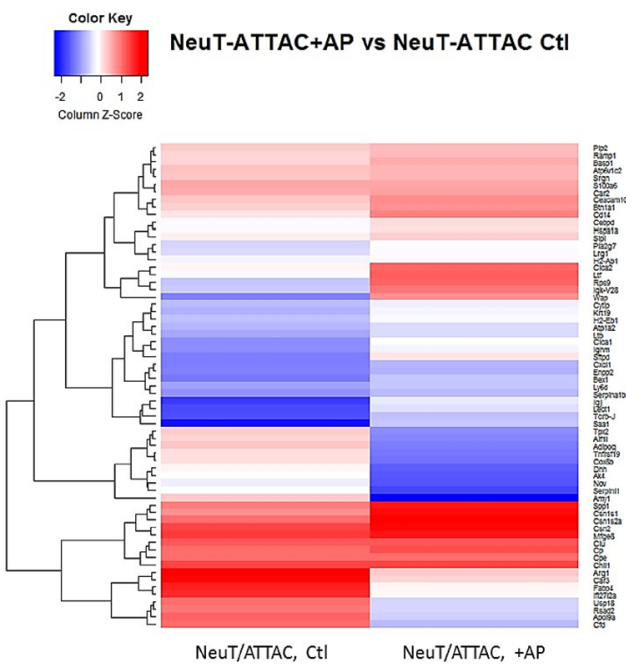

$E$
D

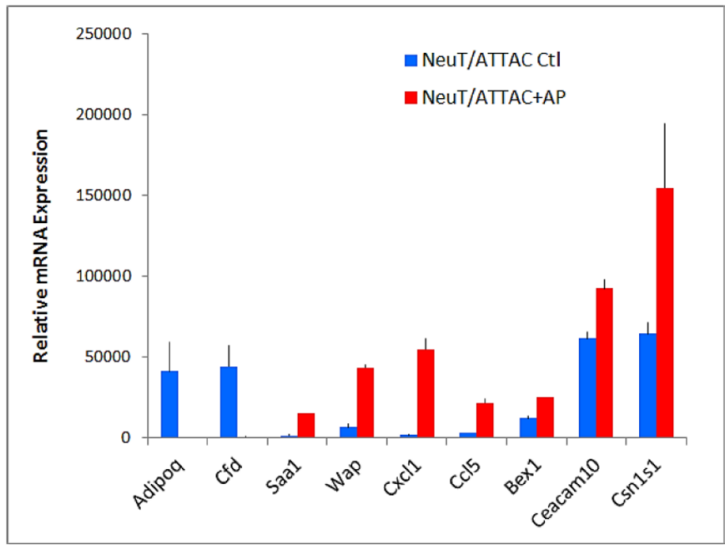

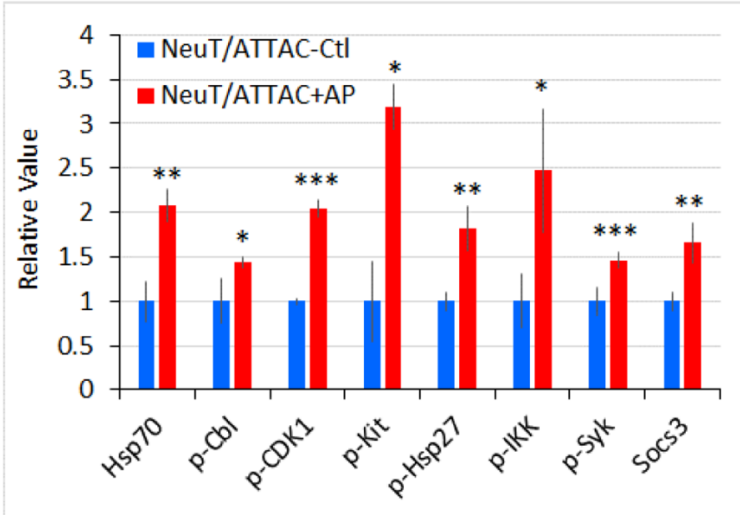

Figure 4: Survival and tumor multiplicity in NeuT/ATTAC mice after induction of fibrosis. (A) NeuT/ATTAC mice were treated with AP21087 as described in Figure 2. Tumor latency was significantly reduced AP21087-treated NeuT/ATTAC mice $(N=9)$ vs. vehicle-treated mice NeuT/ATTAC mice $(N=10)$ using the Mantel-Cox log-rank test $(P<0.0001)$. (B) Tumor multiplicity was significantly increased from $6.3 \pm 0.5$ tumors/mouse (mean \pm S.E.) in vehicle-treated NeuT/ATTAC mice to $14.6 \pm 0.9$ tumors/ mouse in AP-21087-treated NeuT/ATTAC mice using the two-sided Student's $t$ test $(P<0.001)$. (C) Heatmap of the changes in gene expression in NeuT/ATTAC mice treated with vehicle or AP21087 (Supplementary Table 2). RNA was prepared from mammary tumors from each of 5 mice per group and pooled for Affymetrix GeneChip analysis. (D) qRT-PCR analysis of genes selected from the Agilent array in Table 1. (D) qRT-PCR analysis of selected genes in Table 1 and Supplementary Table 2. (E) Immuno-paired antibody detection of signaling pathways in tumors from NeuT/ATTAC mice treated with AP21087 vs vehicle-treated mice as described in Figure 2. The epitopes recognized by the antibodies are described under Materials and Methods. ${ }^{*} P<0.05,{ }^{* *} P<0.02,{ }^{* * *} P<0.01$. 
Table 1: Differentially expressed genes in tumors from NeuT/ATTAC mice 4 months after AP21087 treatment vs. tumors from control NeuT/ATTAC mice at 5.5 months

\begin{tabular}{|c|c|c|c|}
\hline Gene Symbol & Gene Name & AP/Ctl & Function \\
\hline \multicolumn{4}{|c|}{ Adhesion/ECM } \\
\hline Clcal & chloride channel calcium activated 1 & 14.9 & $\begin{array}{l}\text { Adhesion, motility, interacts with } \\
\text { integrin } \beta 4\end{array}$ \\
\hline Clca2 & chloride channel calcium activated 2 & 14.2 & $\begin{array}{l}\text { Adhesion, motility, interacts with } \\
\text { integrin } \beta 4\end{array}$ \\
\hline Krt19 & keratin 19 & 4.7 & Stem cell marker \\
\hline Cpe & carboxypeptidase $\mathrm{E}$ & 3.2 & Adhesion, allograft rejection \\
\hline \multicolumn{4}{|c|}{ Inflammation/Immunity } \\
\hline Saa1 & serum amyloid $\mathrm{A} 1$ & 13.7 & Acute phase protein, inflammation \\
\hline $\mathrm{Cd} 14$ & CD14 antigen & 8.7 & $\begin{array}{l}\text { Macrophage/monocyte marker, TRAF/ } \\
\text { NFкB, inflammation }\end{array}$ \\
\hline Btn1a1 & butyrophilin, subfamily 1 , member A1 & 6.0 & $\begin{array}{l}\text { Inhibits CD4 \& CD8 T cell } \\
\text { development }\end{array}$ \\
\hline Ltb & lymphotoxin B & 3.7 & TRAF signaling, inflammation \\
\hline Cxcl1 & chemokine (C-X-C motif) ligand 1 & 3.6 & Cxcr2 ligand, inflammation \\
\hline $\mathrm{Ccl} 5$ & chemokine (C-C motif) ligand 5 & 3.0 & Ccr1/3/4/5 ligand, inflammation \\
\hline \multicolumn{4}{|c|}{ Invasion/Motility } \\
\hline Spp1 & $\begin{array}{l}\text { secreted phosphoprotein } 1 \\
\text { (osteopontin) }\end{array}$ & 11.8 & Invasion, osteolysis \\
\hline Slpi & secretory leukocyte peptidase inhibitor & 3.6 & Inhibits serine proteases \\
\hline Enpp2 & $\begin{array}{l}\text { ectonucleotide pyrophosphatase/ } \\
\text { phosphodiesterase } 2\end{array}$ & 3.2 & Motility \\
\hline S100a6 & $\begin{array}{l}\text { S100 calcium binding protein A6 } \\
\text { (calcyclin) }\end{array}$ & 3.0 & Motility \\
\hline \multicolumn{4}{|l|}{ Metabolism } \\
\hline Pla2g7 & phospholipase A2, group VII & 3.7 & Produced by inflammatory cells \\
\hline \multicolumn{4}{|l|}{$\underline{\text { Proliferation }}$} \\
\hline Bex1 & brain expressed gene 1 & 4.6 & Cell cycle progression \\
\hline Basp1 & $\begin{array}{l}\text { brain abundant, membrane attached } \\
\text { signal protein } 1\end{array}$ & 4.3 & $\begin{array}{l}\text { Interacts with Hsp } 70 \text {, pre-mRNA } \\
\text { processing, nuclear transport }\end{array}$ \\
\hline Hspala & heat shock protein 1A (Hsp70) & 3.7 & $\begin{array}{l}\text { Mitotic centrosome integrity, inhibits } \\
\text { TGF } \beta \text { signaling }\end{array}$ \\
\hline $\mathrm{Clu}$ & clusterin & 3.4 & $\begin{array}{l}\text { Inhibits apoptosis, degradation of } \\
\text { IKK } \beta\end{array}$ \\
\hline Cd52 & CD52 antigen & 3.0 & $\begin{array}{l}\text { Inhibits tumor suppressor CDKN1B } \\
\text { (p27) }\end{array}$ \\
\hline \multicolumn{4}{|l|}{ Signaling } \\
\hline Cytip & cytohesin 1 interacting protein & 3.8 & SOCS, Jak/Stat signaling \\
\hline Ramp1 & $\begin{array}{l}\text { receptor (calcitonin) activity } \\
\text { modifying protein } 1\end{array}$ & 3.6 & $\begin{array}{l}\text { Prostaglandin E receptor } 2 \text {, calcitonin } \\
\text { \& cAMP signaling }\end{array}$ \\
\hline Lrg1 & leucine-rich alpha-2-glycoprotein 1 & 3.2 & $\begin{array}{l}\text { Activates TGF } \beta \text { signaling, } \\
\text { angiogenesis, granulocyte } \\
\text { differentiation }\end{array}$ \\
\hline \multicolumn{4}{|c|}{ Transcription/Translation } \\
\hline Rps9 & ribosomal protein $\mathrm{S} 9$ & 32.5 & 40S ribosome-mRNA binding \\
\hline
\end{tabular}


Cebpd

CCAAT/enhancer binding protein

(C/EBP), delta

Transport

$\mathrm{Cp}$

Plp2

Atpla2 ceruloplasmin

proteolipid protein 2

ATPase, $\mathrm{Na}+/ \mathrm{K}+$ transporting, alpha 2

polypeptide
4.3 Increases IL6 transcription and the inflammatory response

5.0 Iron transport

3.3 Ion transport and chemokine binding.

3.2 $\mathrm{Na}+/ \mathrm{K}+$ transport, collagen polymerization

Shown are genes with $\geq 3$-fold change in expression and a raw score $\geq 300$ in either group as shown in Supplementary Table 2.

\section{MATERIALS AND METHODS}

\section{Animals}

All animal studies were conducted under protocol 2016-1143 approved by the Georgetown University Animal Care and Use Committee in accordance with NIH guidelines for the ethical treatment of animals. MMTVNeuT mice [46] were obtained from Jackson Labs (FVB-Tg(MMTV-Erbb2)NK1Mul/J), and exhibit 100\% penetrance of mammary tumorigenesis by $6-7$ months [47]. FAT-ATTAC mice on a C57BL/6 background were kindly provided by Dr. Philipp Scherer, University of Texas Southwestern $[28,48]$. Mice were crossed into the FVB strain for four generations before crossing with MMTV-NeuT mice to produce NeuT/ATTAC mice. A schematic of the breeding is shown in Figure 1A.

\section{Induction of fibrosis}

Animals at 6 weeks of age were treated weekly by i.p. injection of $0.4 \mathrm{mg} / \mathrm{kg}$ AP2 1087 dissolved in vehicle (4\% ethanol, $10 \%$ PEG-400, and $1.75 \%$ Tween-20 in water) or with vehicle alone on Monday, Wednesday and Friday for the periods indicated. Mammary gland whole mounts were prepared to assess end-bud formation and ductal branching as previously described following two weeks of AP2 1087 treatment [45, 49, 50] (Figure 1B). Fat

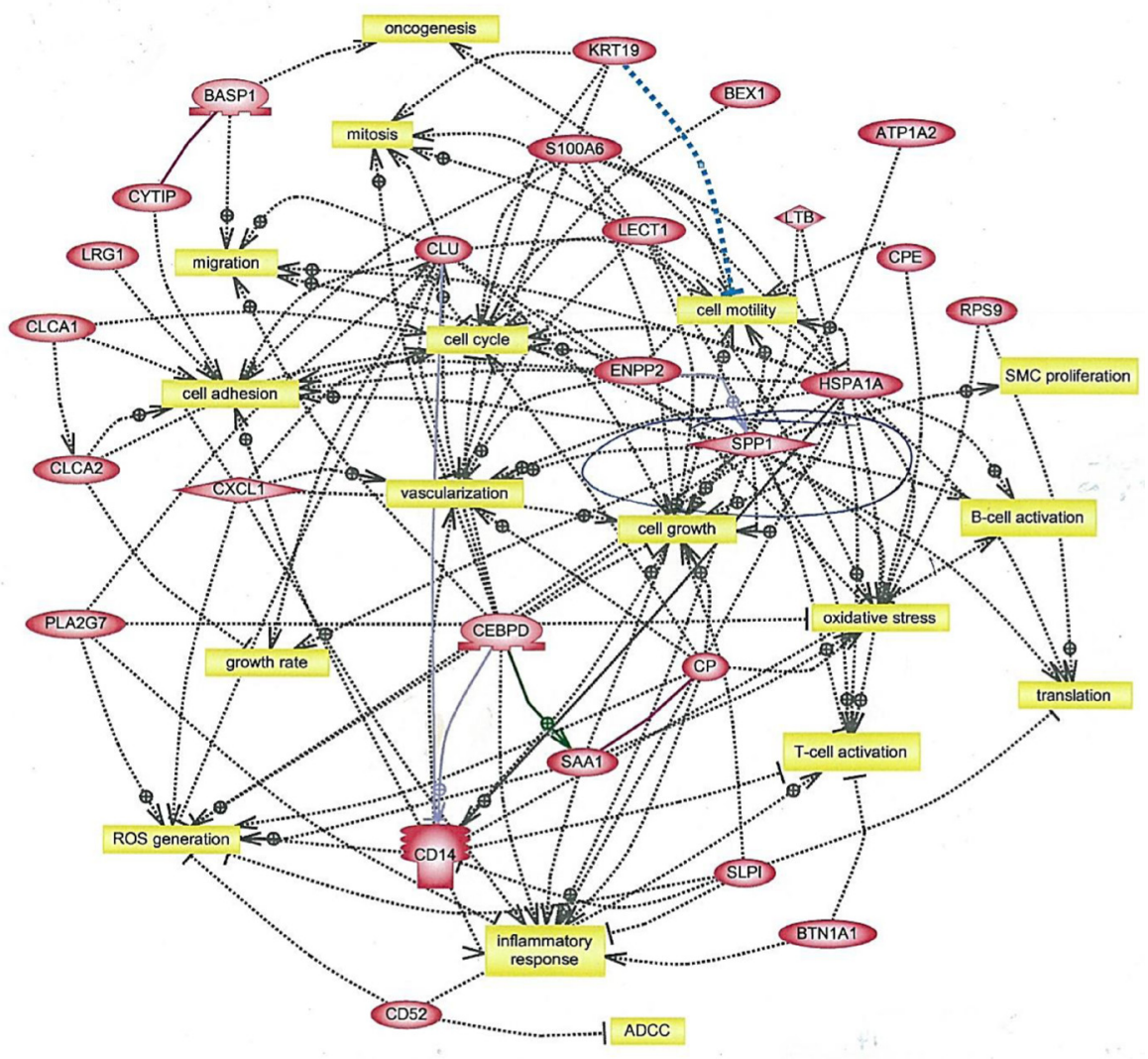

Figure 5: Interaction analysis of genes upregulated in tumors from AP21087-treated vs. vehicle-treated NeuT/ATTAC mice. Mice were treated as described in Figure 2, and gene interactions were determined with Ariadne Pathway Studio version 9.1. The full list of gene expression changes in presented in Supplementary Table 2. ADCC, antibody-dependent cytotoxicity. 
ablation was assessed by H\&E staining of formalin-fixed paraffin-embedded (FFPE) sections that were prepared by the Histopathology \& Tissue Shared Resource, Georgetown University.

\section{Histopathology and immunohistochemistry}

Mammary tissue was excised and FFPE sections were prepared for antigen retrieval by incubation in 10 $\mathrm{mM}$ sodium citrate buffer $(\mathrm{pH}$ 6.0) for $20 \mathrm{~min}$ at a subboiling temperature in an electric steamer as previously described [45, 50, 51]. Endogenous peroxidase activity was quenched with 3\% hydrogen peroxide for $10 \mathrm{~min}$, and incubated for $30 \mathrm{~min}$ with blocking solution (10\% goat serum in Tris-buffered saline), followed by incubation overnight at $4^{\circ} \mathrm{C}$ with the appropriate primary antibody diluted in blocking solution. Biotin-conjugated secondary antibodies were diluted in TBS containing $0.1 \%$ Tween-20 and incubated for $30 \mathrm{~min}$ at room temperature using the ABC Vectastain (Vector Laboratories) detection system and diaminobenzidine (Pierce), and slides were counterstained with Harris-modified hematoxylin (Thermo-Fisher, Inc.), dehydrated and mounted in Permount (Thermo-Fisher, Inc.). Antibodies and their dilutions for IHC are listed in Supplementary Table 1.

\section{Gene microarray analysis}

At the appropriate intervals, animals were euthanized by $\mathrm{CO}_{2}$ asphyxiation, and tissue excised and snap-frozen in liquid nitrogen for gene expression profiling [45, 50-54]. Briefly, snap-frozen tissue was pulverized in a mortar and pestle and RNA extracted using an RNeasy Mini Kit (Qiagen) according to the manufacturer's protocol. RNA purity was assessed by the integrity of $18 \mathrm{~S}$ and 28S rRNA using an Agilent microfluidic chip. Array analysis was carried out with cRNA prepared from equal amounts of RNA $(1 \mu \mathrm{g})$ pooled from 3 mice per group. Biotin-labeled cRNA was fragmented at $94^{\circ} \mathrm{C}$ for $35 \mathrm{~min}$ and hybridized overnight to an Affymetrix mouse 430A 2.0 GeneChip ${ }^{\circledR}$, and scanned with an Agilent Gene Array scanner. Affymetrix GeneChip ${ }^{\circledR}$ Operating software 1.1 was used for grid alignment and raw data generation. A noise value $(Q)$ based on the variance of low-intensity probe cells was used to calculate a minimum threshold for each GeneChip. Samples were averaged and data refined by eliminating genes with signal intensities $<300$ in both comparison groups, and heat maps were generated from $\geq 3$-fold changes in gene expression normalized to control tissue using unsupervised hierarchical cluster analysis as previously described [55]. Gene expression data for mammary tissue after four months of AP21087 treatment are presented in Supplementary Table 2, and data for tumor tissue after four weeks of AP21087 treatment are presented in Supplementary Table 3. Gene interaction analysis of genes upregulated $\geq 3$-fold following four months of AP21087 treatment was determined using Ariadne Pathway Studio version 9.1. Data sets have been deposited in the GEO public database under accession no. GSE78202.

\section{Quantitative real-time polymerase chain reaction (qRT-PCR)}

Total RNA was extracted as described above and RNA $(1 \mu \mathrm{g})$ from each of 3 samples per group was reverse transcribed using the Omniscript RT kit (Qiagen) as previously described [50-54]. PCR was performed in triplicate using an ABI-Prism 7700 (Applied Biosystems) with SYBRGreen I detection (Qiagen) according to the manufacturer's protocol. Amplification using the appropriate primers was confirmed by ethidium bromide staining of the PCR products on an agarose gel. The expression of each target gene was normalized to GAPDH and is presented as the ratio of the target gene to GADPH expression calculated using the formula, $2^{-\Delta \mathrm{Ct}}$, where $\Delta \mathrm{Ct}$ $=\mathrm{Ct}^{\text {Target }}-\mathrm{Ct}^{18 \mathrm{~s}}[53]$. A list of primers used for qRT-PCR is presented in Supplementary Table 4.

\section{Immuno-paired antibody detection (IPAD) analysis}

Triplicate $5 \mathrm{~m} \mu$ sections of FFPE tissues were deparaffinized with xylene, rehydrated through a series of graded alcohol solutions and extracted for $10 \mathrm{~min}$ at $37^{\circ} \mathrm{C}$ with a buffer containing phosphate-buffered saline and $1 \%$ SDS using a proprietary procedure for IPAD analysis (https:/www.activsignal.com/technology). The IPAD platform measures the activity of multiple signaling pathways in a single reaction in a 96-well high-throughput format. Approximately $150 \mathrm{ng}$ of total protein lysate were analyzed per well to assess the activities of more than 70 target proteins in 20 signaling pathways using two distinct oligo-tagged antibodies per target. The combined tags were quantitated by digital PCR using a Fluidigm Biomark apparatus (Fluidigm). Phosphoantibodies detected pY700Cbl, pY15-CDK1, pY730-c-Kit, pS78/82-HSPB1/Hsp27, pS176/180-IKK and pY525/526-Syk.

\section{Statistical analysis}

Statistical significance of means \pm S.D. were evaluated using the two-tailed Student's $t$ test at a significance of $P<0.05$. Differences in tumor growth in vivo were determined by the unpaired two-tailed Student's $t$ test at a significance of $P<0.05$ using Prism GraphPad software. 


\section{ACKNOWLEDGMENTS AND FUNDING}

This work was supported by grants from the Nina Hyde Foundation, the Avon Foundation for Women, contract 1NO1 CN43302-WA19 from the National Cancer Institute, NIH, and award 1P30 CA051008 from the National Cancer Institute, NIH, to the Lombardi Comprehensive Cancer Center (LCCC). This investigation was conducted using the Animal Research, Genomics and Epigenomics, Tissue and Histology, and Microscopy and Imaging Shared Resources of the LCCC, and by an animal facilities construction grant from the NIH.

\section{CONFLICTS OF INTEREST}

None.

\section{REFERENCES}

1. Hanahan D, Weinberg RA. The hallmarks of cancer. Cell. 2000; 100:57-70.

2. Polyak K, Haviv I, Campbell IG. Co-evolution of tumor cells and their microenvironment. Trends Genet. 2009; 25:30-8. https://doi.org/10.1016/j.tig.2008.10.012.

3. Pietras K, Ostman A. Hallmarks of cancer: interactions with the tumor stroma. Exp Cell Res. 2010; 316:1324-31. https:// doi.org/10.1016/j.yexcr.2010.02.045.

4. Hanahan D, Weinberg RA. Hallmarks of cancer: the next generation. Cell. 2011; 144:646-74. https://doi. org/10.1016/j.cell.2011.02.013.

5. Hanahan D, Coussens LM. Accessories to the crime: functions of cells recruited to the tumor microenvironment. Cancer Cell. 2012; 21:309-22. https://doi.org/10.1016/j. ccr.2012.02.022.

6. Tchou J, Conejo-Garcia J. Targeting the tumor stroma as a novel treatment strategy for breast cancer: shifting from the neoplastic cell-centric to a stroma-centric paradigm. Adv Pharmacol. 2012; 65:45-61. https://doi.org/10.1016/ B978-0-12-397927-8.00003-8.

7. Oza AM, Boyd NF. Mammographic parenchymal patterns: a marker of breast cancer risk. Epidemiol Rev. 1993; 15:196-208.

8. Boyd NF, Lockwood GA, Byng JW, Tritchler DL, Yaffe MJ. Mammographic densities and breast cancer risk. Cancer Epidemiol Biomarkers Prev. 1998; 7:1133-44.

9. Hasebe T, Mukai K, Tsuda H, Ochiai A. New prognostic histological parameter of invasive ductal carcinoma of the breast: clinicopathological significance of fibrotic focus. Pathol Int. 2000; 50:263-72.

10. Pang JM, Byrne DJ, Takano EA, Jene N, Petelin L, McKinley J, Poliness C, Saunders C, Taylor D, Mitchell G, Fox SB. Breast Tissue Composition and Immunophenotype and Its Relationship with Mammographic Density in
Women at High Risk of Breast Cancer. PLoS One. 2015; 10:e0128861. https://doi.org/10.1371/journal.pone.0128861.

11. Van den Eynden GG, Colpaert CG, Couvelard A, Pezzella F, Dirix LY, Vermeulen PB, Van Marck EA, Hasebe T. A fibrotic focus is a prognostic factor and a surrogate marker for hypoxia and (lymph)angiogenesis in breast cancer: review of the literature and proposal on the criteria of evaluation. Histopathology. 2007; 51:440-51. https://doi. org/10.1111/j.1365-2559.2007.02761.x.

12. Gill JK, Maskarinec G, Pagano I, Kolonel LN. The association of mammographic density with ductal carcinoma in situ of the breast: the Multiethnic Cohort. Breast Cancer Res. 2006; 8:R30. https://doi.org/10.1186/bcr1507.

13. Hasebe T. Tumor-stromal interactions in breast tumor progression--significance of histological heterogeneity of tumor-stromal fibroblasts. Expert Opin Ther Targets. 2013; 17:449-60. https://doi.org/10.1517/14728222.2013.757305.

14. Boyd NF, Martin LJ, Bronskill M, Yaffe MJ, Duric N, Minkin S. Breast tissue composition and susceptibility to breast cancer. J Natl Cancer Inst. 2010; 102:1224-37. https://doi.org/10.1093/jnci/djq239.

15. Park J, Scherer PE. Leptin and cancer: from cancer stem cells to metastasis. Endocr Relat Cancer. 2011; 18:C25-9. https://doi.org/10.1530/ERC-11-0163.

16. Zheng Q, Dunlap SM, Zhu J, Downs-Kelly E, Rich J, Hursting SD, Berger NA, Reizes O. Leptin deficiency suppresses MMTV-Wnt-1 mammary tumor growth in obese mice and abrogates tumor initiating cell survival. Endocr Relat Cancer. 2011; 18:491-503. https://doi.org/10.1530/ ERC-11-0102.

17. Orimo A, Gupta PB, Sgroi DC, Arenzana-Seisdedos F, Delaunay T, Naeem R, Carey VJ, Richardson AL, Weinberg RA. Stromal fibroblasts present in invasive human breast carcinomas promote tumor growth and angiogenesis through elevated SDF-1/CXCL12 secretion. Cell. 2005; 121:335-48. https://doi.org/10.1016/j.cell.2005.02.034.

18. Acharyya S, Oskarsson $\mathrm{T}$, Vanharanta $\mathrm{S}$, Malladi $\mathrm{S}$, Kim J, Morris PG, Manova-Todorova K, Leversha M, Hogg N, Seshan VE, Norton L, Brogi E, Massague J. A CXCL1 paracrine network links cancer chemoresistance and metastasis. Cell. 2012; 150:165-78. https://doi. org/10.1016/j.cell.2012.04.042.

19. Oladipo O, Conlon S, O'Grady A, Purcell C, Wilson C, Maxwell PJ, Johnston PG, Stevenson M, Kay EW, Wilson $\mathrm{RH}$, Waugh DJ. The expression and prognostic impact of CXC-chemokines in stage II and III colorectal cancer epithelial and stromal tissue. Br J Cancer. 2011; 104:480-7. https://doi.org/10.1038/sj.bjc.6606055.

20. Miyake M, Lawton A, Goodison S, Urquidi V, GomesGiacoia E, Zhang G, Ross S, Kim J, Rosser CJ. Chemokine (C-X-C) ligand 1 (CXCL1) protein expression is increased in aggressive bladder cancers. BMC Cancer. 2013; 13:322. https://doi.org/10.1186/1471-2407-13-322. 
21. Miyake M, Lawton A, Goodison S, Urquidi V, Rosser CJ. Chemokine (C-X-C motif) ligand 1 (CXCL1) protein expression is increased in high-grade prostate cancer. Pathol Res Pract. 2014; 210:74-8. https://doi.org/10.1016/j. prp.2013.08.013.

22. Grivennikov SI, Greten FR, Karin M. Immunity, inflammation, and cancer. Cell. 2010; 140:883-99. https:// doi.org/10.1016/j.cell.2010.01.025.

23. Mellman I, Coukos G, Dranoff G. Cancer immunotherapy comes of age. Nature. 2011; 480:480-9. https://doi. org/10.1038/nature10673.

24. Pardoll DM. The blockade of immune checkpoints in cancer immunotherapy. Nat Rev Cancer. 2012; 12:252-64. https:// doi.org/10.1038/nrc3239.

25. Jamieson T, Clarke M, Steele CW, Samuel MS, Neumann J, Jung A, Huels D, Olson MF, Das S, Nibbs RJ, Sansom OJ. Inhibition of CXCR2 profoundly suppresses inflammationdriven and spontaneous tumorigenesis. J Clin Invest. 2012; 122:3127-44. https://doi.org/10.1172/JCI61067.

26. Highfill SL, Cui Y, Giles AJ, Smith JP, Zhang H, Morse E, Kaplan RN, Mackall CL. Disruption of CXCR2-mediated MDSC tumor trafficking enhances anti-PD1 efficacy. Sci Transl Med. 2014; 6:237ra67. https://doi.org/10.1126/ scitranslmed.3007974.

27. Li T, Sun L, Miller N, Nicklee T, Woo J, Hulse-Smith L, Tsao MS, Khokha R, Martin L, Boyd N. The association of measured breast tissue characteristics with mammographic density and other risk factors for breast cancer. Cancer Epidemiol Biomarkers Prev. 2005; 14:343-9. https://doi. org/10.1158/1055-9965.EPI-04-0490.

28. Pajvani UB, Trujillo ME, Combs TP, Iyengar P, Jelicks L, Roth KA, Kitsis RN, Scherer PE. Fat apoptosis through targeted activation of caspase 8: a new mouse model of inducible and reversible lipoatrophy. Nat Med. 2005; 11:797-803. https://doi.org/10.1038/nm1262.

29. Ma XJ, Dahiya S, Richardson E, Erlander M, Sgroi DC. Gene expression profiling of the tumor microenvironment during breast cancer progression. Breast Cancer Res. 2009; 11:R7. https://doi.org/10.1186/bcr2222.

30. Finak G, Bertos N, Pepin F, Sadekova S, Souleimanova M, Zhao H, Chen H, Omeroglu G, Meterissian S, Omeroglu A, Hallett M, Park M. Stromal gene expression predicts clinical outcome in breast cancer. Nat Med. 2008; 14:518 27. https://doi.org/10.1038/nm1764.

31. Bhowmick NA, Neilson EG, Moses HL. Stromal fibroblasts in cancer initiation and progression. Nature. 2004; 432:3327. https://doi.org/10.1038/nature03096.

32. Kalluri R, Zeisberg M. Fibroblasts in cancer. Nat Rev Cancer. 2006; 6:392-401. https://doi.org/10.1038/nrc1877.

33. Harper J, Sainson RC. Regulation of the anti-tumour immune response by cancer-associated fibroblasts. Semin Cancer Biol. 2014; 25:69-77. https://doi.org/10.1016/j. semcancer.2013.12.005.
34. Ortiz-Martinez F, Perez-Balaguer A, Ciprian D, Andres L, Ponce J, Adrover E, Sanchez-Paya J, Aranda FI, Lerma E, Peiro G. Association of increased osteopontin and splice variant-c mRNA expression with HER2 and triple-negative/ basal-like breast carcinomas subtypes and recurrence. Hum Pathol. 2014; 45:504-12. https://doi.org/10.1016/j. humpath.2013.10.015.

35. Di Mitri D, Toso A, Chen JJ, Sarti M, Pinton S, Jost TR, D'Antuono R, Montani E, Garcia-Escudero R, Guccini I, Da Silva-Alvarez S, Collado M, Eisenberger M, et al. Tumour-infiltrating Gr-1+ myeloid cells antagonize senescence in cancer. Nature. 2014; 515:134-7. https://doi. org/10.1038/nature13638.

36. Zou A, Lambert D, Yeh H, Yasukawa K, Behbod F, Fan F, Cheng N. Elevated CXCL1 expression in breast cancer stroma predicts poor prognosis and is inversely associated with expression of TGF-beta signaling proteins. BMC Cancer. 2014; 14:781. https://doi. org/10.1186/1471-2407-14-781.

37. Ijichi H, Chytil A, Gorska AE, Aakre ME, Bierie B, Tada M, Mohri D, Miyabayashi K, Asaoka Y, Maeda S, Ikenoue T, Tateishi K, Wright CV, et al. Inhibiting Cxcr2 disrupts tumor-stromal interactions and improves survival in a mouse model of pancreatic ductal adenocarcinoma. $\mathrm{J}$ Clin Invest. 2011; 121:4106-17. https://doi.org/10.1172/ JCI42754.

38. Stadtmann A, Zarbock A. CXCR2: From Bench to Bedside. Front Immunol. 2012; 3:263. https://doi.org/10.3389/ fimmu.2012.00263.

39. Horuk R. Chemokine receptor antagonists: overcoming developmental hurdles. Nat Rev Drug Discov. 2009; 8:2333. https://doi.org/10.1038/nrd2734.

40. Gioni V, Karampinas T, Voutsinas G, Roussidis AE, Papadopoulos S, Karamanos NK, Kletsas D. Imatinib mesylate inhibits proliferation and exerts an antifibrotic effect in human breast stroma fibroblasts. Mol Cancer Res. 2008; 6:706-14. https://doi.org/10.1158/1541-7786. MCR-07-0355.

41. Cannarile MA, Weisser M, Jacob W, Jegg AM, Ries CH, Ruttinger D. Colony-stimulating factor 1 receptor (CSF1R) inhibitors in cancer therapy. J Immunother Cancer. 2017; 5:53. https://doi.org/10.1186/s40425-017-0257-y.

42. Xu W, Mimnaugh E, Rosser MF, Nicchitta C, Marcu M, Yarden Y, Neckers L. Sensitivity of mature Erbb2 to geldanamycin is conferred by its kinase domain and is mediated by the chaperone protein Hsp90. J Biol Chem. 2001; 276:3702-8. https://doi.org/10.1074/jbc. M006864200.

43. Khan $\mathrm{T}$, Muise ES, Iyengar $\mathrm{P}$, Wang ZV, Chandalia M, Abate N, Zhang BB, Bonaldo P, Chua S, Scherer PE. Metabolic dysregulation and adipose tissue fibrosis: role of collagen VI. Mol Cell Biol. 2009; 29:1575-91. https://doi. org/10.1128/MCB.01300-08. 
44. Mercier I, Camacho J, Titchen K, Gonzales DM, Quann K, Bryant KG, Molchansky A, Milliman JN, WhitakerMenezes D, Sotgia F, Jasmin JF, Schwarting R, Pestell RG, et al. Caveolin-1 and accelerated host aging in the breast tumor microenvironment: chemoprevention with rapamycin, an mTOR inhibitor and anti-aging drug. Am J Pathol. 2012; 181:278-93. https://doi.org/10.1016/j. ajpath.2012.03.017.

45. Yuan H, Lu J, Xiao J, Upadhyay G, Umans R, Kallakury B, Yin Y, Fant ME, Kopelovich L, Glazer RI. PPARdelta induces estrogen receptor-positive mammary neoplasia through an inflammatory and metabolic phenotype linked to mTOR activation. Cancer Res. 2013; 73:4349-61. https:// doi.org/10.1158/0008-5472.CAN-13-0322.

46. Muller WJ, Sinn E, Pattengale PK, Wallace R, Leder P. Single-step induction of mammary adenocarcinoma in transgenic mice bearing the activated c-neu oncogene. Cell. 1988; 54:105-15.

47. Guy CT, Cardiff RD, Muller WJ. Induction of metastatic mammary tumors by expression of polyoma middle $\mathrm{T}$ oncogene: a transgenic mouse model for metastatic disease. Mol Cell Biol. 1992; 12:954-61.

48. Landskroner-Eiger S, Park J, Israel D, Pollard JW, Scherer PE. Morphogenesis of the developing mammary gland: stage-dependent impact of adipocytes. Dev Biol. 2010; 344:968-78. https://doi.org/10.1016/j.ydbio.2010.06.019.

49. Ackler S, Ahmad S, Tobias C, Johnson MD, Glazer RI. Delayed mammary gland involution in MMTV-AKT1 transgenic mice. Oncogene. 2002; 21:198-206. https://doi. org/10.1038/sj.onc.1205052.

50. Yin Y, Yuan H, Zeng X, Kopelovich L, Glazer RI. Inhibition of peroxisome proliferator-activated receptor gamma increases estrogen receptor-dependent tumor specification. Cancer Res. 2009; 69:687-94. https://doi.org/10.1158/00085472.CAN-08-2446.

51. Yin Y, Russell RG, Dettin LE, Bai R, Wei ZL, Kozikowski AP, Kopelovich L, Glazer RI. Peroxisome proliferatoractivated receptor delta and gamma agonists differentially alter tumor differentiation and progression during mammary carcinogenesis. Cancer Res. 2005; 65:3950-7.

52. Pollock CB, Yin Y, Yuan H, Zeng X, King S, Li X, Kopelovich L, Albanese C, Glazer RI. PPARdelta activation acts cooperatively with 3-phosphoinositide-dependent protein kinase-1 to enhance mammary tumorigenesis. PLoS One. 2011; 6:e16215. https://doi.org/10.1371/journal. pone. 0016215.

53. Upadhyay G, Yin Y, Yuan H, Li X, Derynck R, Glazer RI. Stem cell antigen-1 enhances tumorigenicity by disruption of growth differentiation factor-10 (GDF10)-dependent TGF-beta signaling. Proc Natl Acad Sci U S A. 2011; 108:7820-5. https://doi.org/10.1073/pnas.1103441108.

54. Yin Y, Bai R, Russell RG, Beildeck ME, Xie Z, Kopelovich L, Glazer RI. Characterization of medroxyprogesterone and DMBA-induced multilineage mammary tumors by gene expression profiling. Mol Carcinog. 2005; 44:42-50. https:// doi.org/10.1002/mc.20119.

55. Herschkowitz JI, Simin K, Weigman VJ, Mikaelian I, Usary J, Hu Z, Rasmussen KE, Jones LP, Assefnia S, Chandrasekharan S, Backlund MG, Yin Y, Khramtsov AI, et al. Identification of conserved gene expression features between murine mammary carcinoma models and human breast tumors. Genome Biol. 2007; 8:R76. https://doi. org/10.1186/gb-2007-8-5-r76. 